February 2005 - NREL/CP-520-37357

\title{
Crystalline Silicon Short-Circuit Current Degradation Study: Initial Results
}

C.R. Osterwald, J. Pruett, and T. Moriarty

Prepared for the $31^{\text {st }}$ IEEE Photovoltaics Specialists Conference and Exhibition

Lake Buena Vista, Florida

January 3-7, 2005
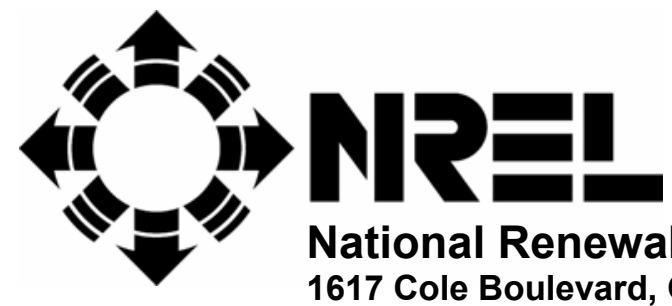

National Renewable Energy Laboratory 1617 Cole Boulevard, Golden, Colorado 80401-3393 303-275-3000 • www.nrel.gov

Operated for the U.S. Department of Energy

Office of Energy Efficiency and Renewable Energy

by Midwest Research Institute $\bullet$ Battelle

Contract No. DE-AC36-99-G010337 


\section{NOTICE}

The submitted manuscript has been offered by an employee of the Midwest Research Institute (MRI), a contractor of the US Government under Contract No. DE-AC36-99G010337. Accordingly, the US Government and MRI retain a nonexclusive royalty-free license to publish or reproduce the published form of this contribution, or allow others to do so, for US Government purposes.

This report was prepared as an account of work sponsored by an agency of the United States government. Neither the United States government nor any agency thereof, nor any of their employees, makes any warranty, express or implied, or assumes any legal liability or responsibility for the accuracy, completeness, or usefulness of any information, apparatus, product, or process disclosed, or represents that its use would not infringe privately owned rights. Reference herein to any specific commercial product, process, or service by trade name, trademark, manufacturer, or otherwise does not necessarily constitute or imply its endorsement, recommendation, or favoring by the United States government or any agency thereof. The views and opinions of authors expressed herein do not necessarily state or reflect those of the United States government or any agency thereof.

Available electronically at http://www.osti.gov/bridge

Available for a processing fee to U.S. Department of Energy and its contractors, in paper, from:

U.S. Department of Energy

Office of Scientific and Technical Information

P.O. Box 62

Oak Ridge, TN 37831-0062

phone: 865.576 .8401

fax: 865.576.5728

email: mailto:reports@adonis.osti.gov

Available for sale to the public, in paper, from:

U.S. Department of Commerce

National Technical Information Service

5285 Port Royal Road

Springfield, VA 22161

phone: 800.553 .6847

fax: 703.605.6900

email: orders@ntis.fedworld.gov

online ordering: http://www.ntis.gov/ordering.htm 


\title{
CRYSTALLINE SILICON SHORT-CIRCUIT CURRENT DEGRADATION STUDY: INITIAL RESULTS
}

\author{
C.R. Osterwald, J. Pruett, and T. Moriarty \\ National Renewable Energy Laboratory (NREL), Golden, CO 80401
}

\begin{abstract}
Following our observation of slow degradation of short-circuit current $\left(I_{s c}\right)$ in crystalline silicon $(x-S i)$ modules that was correlated with ultraviolet (UV) exposure dose, we initiated a new study of individual $\mathrm{x}$-Si cells designed to determine the degradation cause. In this paper, we report the initial results of this study, which has accumulated $1056 \mathrm{MJ} / \mathrm{m}^{2}$ of UV dose from 1-sun metal-halide irradiance, equivalent to 3.8 years at our test site. At this time, the control samples are unchanged, the unencapsulated samples have lost about $2 \%$ of $I_{s c}$, and the samples encapsulated in module-style packages have declined from $1 \%$ to $3 \%$, depending on the cell technology.
\end{abstract}

\section{INTRODUCTION}

Previously, we reported slow $(0.25 \%$ to $0.60 \%$ per year) degradation of $\mathrm{I}_{\mathrm{sc}}$ in $\mathrm{x}$-Si modules that were stressed with real-time outdoor, accelerated outdoor, and accelerated indoor exposure techniques [1-3]. The degradation rates were linear with the total UV radiation exposure doses (our outdoor test site averages $274 \mathrm{MJ} / \mathrm{m}^{2}$ of total UV per year). Several possible causes of the slow degradation were identified: 1) obscuration or absorption in the glass superstrate, 2) obscuration or absorption in the ethylene vinyl acetate (EVA) encapsulant, 3) degradation of the antireflection (AR) coatings, or 4) degradation of the $p$ $\mathrm{n}$ junctions. Isolating these possible causes in modules is not an easy task. Because modules contain a large number of cells connected in series, nondestructive currentvoltage (I-V) and quantum efficiency (QE) measurements on individual cells are quite difficult or impossible. Nondestructive measurements of the superstrate glass and encapsulate materials are also impossible. Consideration of all the available evidence seemed to rule out obscuration or absorption (the first two causes), but we were unable to determine if the losses were caused by changes to the AR coatings or to the $p-n$ junctions. The QE data from these modules showed that about $75 \%$ of the $\mathrm{I}_{\mathrm{sc}}$ losses occurred at wavelengths longer than $800 \mathrm{~nm}$, which was inconsistent with browning of EVA [4].

Because of the correlation with the total UV dose for all exposure methods, and because one indoor method used only UVA-340 fluorescent radiation, we hypothesized that UV radiation was responsible for the observed slow degradation. Although we suspected that a simple thermal process was not responsible, we were not able to conclusively eliminate this cause. Therefore, in 2003, we initiated a new experiment using a sample set consisting of individual $\mathrm{x}-\mathrm{Si}$, cells instead of modules, that was designed to isolate the exact cause of the observed $I_{s c}$ degradation, if possible. If a thermal process is responsible for the degradation, cells stressed at elevated temperatures in the dark should degrade. On the other hand, if UV damage is responsible, unencapsulated samples should degrade faster than conventional module packaged samples, and cells that have UV blocking should show no degradation. The experiment will be run until at least ten years of equivalent outdoor exposure is accumulated.

Three different types of $x$-Si cells were obtained from the same two manufacturers that produced the modules used in the previous study. These are: 1) cast poly-Si with $\mathrm{TiO}_{2}$ antireflection coating, 2) single-crystal Czochralski $(\mathrm{Cz}) \mathrm{Si}$ with $\mathrm{TiO}_{2}$ AR coating, and 3) single-crystal $\mathrm{Cz}-\mathrm{Si}$ with textured front surface and no AR coating. All cells have factory-soldered ribbons for contacts, and the cells were assembled into three different package types: 1) unencapsulated (bonded to glass substrates with silicone rubber), 2) AFG Solatex/EVA encapsulation, and 3) Schott GG 495/EVA (UV-blocking colored glass) encapsulation. The encapsulated samples all have conventional Tedlarpolyester-Tedlar (TPT) backsheets. There is a total of eight cells of each type. Six of each type are currently being exposed to metal-halide 1-sun illumination inside an environmental chamber with the ambient temperature controlled to $18^{\circ} \mathrm{C}$, which results in cell temperatures in the range $53^{\circ}-63^{\circ} \mathrm{C}$. No humidity is introduced into the chamber. UV irradiance is measured with an Eppley Total UV Radiometer (TUVR) calibrated by the NREL Solar Radiation Research Laboratory. One unencapsulated sample of each type is held in an oven at $55^{\circ}-60^{\circ} \mathrm{C}$ without light, and three unencapsulated samples are retained as controls and are not stressed. The test protocol called for careful light I-V, dark I-V, and QE measurements of all cells initially and at each intermediate step when the exposure is interrupted. Light I-V measurements are made in accordance with ASTM E 948 [5].

\section{RESULTS TO DATE}

At the time of this writing, the samples have accumulated a total UV dose of $1056 \mathrm{MJ} / \mathrm{m}^{2}$. There have been no measurable changes to the open-circuit voltages $( \pm 2 \mathrm{mV}$ 
out of $600 \mathrm{mV}$ ), and one unencapsulated cell has a $10 \%$ loss of fill factor due to an increased series resistance. We note that none of the cells showed the rapid initial light-induced degradation of $\mathrm{I}_{\mathrm{sc}}$ due to the boron-oxygen metastability in p-type Si solar cells [6]. It is not known if the cells were light soaked by the manufacturers prior to delivery.

\section{Control and oven samples}

Figures 1 and 2 show the measured $\mathrm{I}_{\mathrm{sc}}$ values of the control and oven samples as a function of the total UV exposure dose, normalized to the initial baseline measurements. Although these samples were not exposed in the environmental chamber, they were retested at the same times with the exposed samples. These two plots demonstrate the excellent repeatability of the NREL standard cell measurement facility for $\mathrm{I}_{\mathrm{sc}}$. Comparison of the oven-exposed samples with the controls indicates there are no detectable changes.

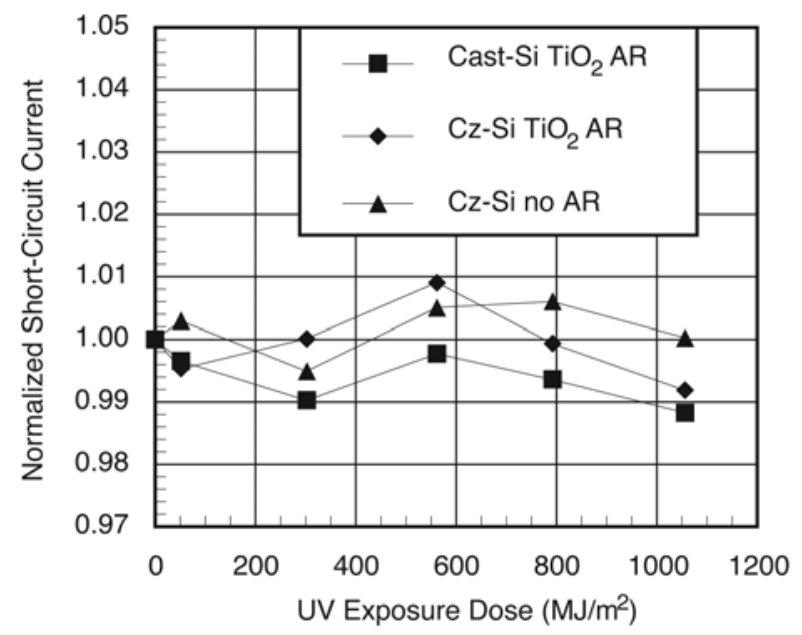

Fig. 1. Normalized $\mathrm{I}_{\mathrm{sc}}$ versus total UV exposure dose for the unexposed control samples.

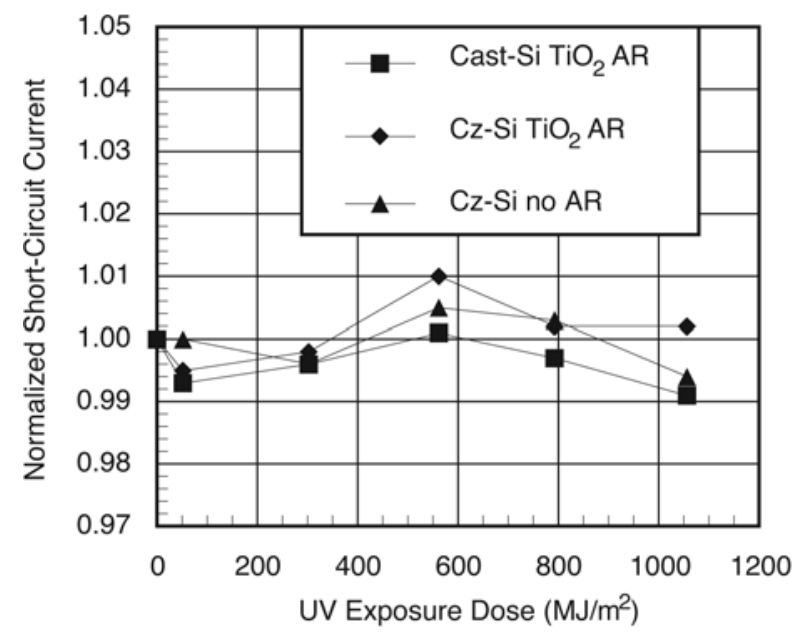

Fig. 2. Normalized $I_{\mathrm{sc}}$ versus total UV exposure dose for the samples held at $53^{\circ}-63^{\circ} \mathrm{C}$ in the dark.

\section{Solatex/EVA-encapsulated samples}

The EVA-encapsulated samples are beginning to show losses of $\mathrm{I}_{\mathrm{sc}}$, which are listed in Table 1. With correlation coefficients near zero, it cannot be concluded that the cast-Si $\mathrm{TiO}_{2}$ samples have changed. The $\mathrm{Cz}-\mathrm{Si} \mathrm{TiO}_{2}$ samples, on the other hand, have linear correlation coefficients higher than 0.9; these trends are plotted in Fig. 3. Figure 4 shows the changes in the absolute QE for one of these samples (\#2); note that all losses have occurred at wavelengths shorter than $700 \mathrm{~nm}$.

Table 1. $I_{s c}$ degradation rates and linear-fit correlation coefficients for the samples encapsulated with EVA in module-style packages under Solatex superstrates.

\begin{tabular}{|l|c|c|}
\hline \multicolumn{1}{|c|}{ Sample } & $\begin{array}{c}\text { Rate } \\
\left(\% / \mathrm{GJ} / \mathrm{m}^{2}\right)\end{array}$ & $\mathrm{r}^{2}$ \\
\hline Cast-Si TiO 2 AR \#1 & +0.15 & 0.024 \\
\hline Cast-Si TiO 2 AR \#2 & -0.51 & 0.173 \\
\hline $\mathrm{Cz}_{\mathrm{Si} \mathrm{TiO}}$ AR \#1 & -2.41 & 0.908 \\
\hline $\mathrm{Cz}-\mathrm{Si} \mathrm{TiO}$ AR \#2 & -2.70 & 0.906 \\
\hline $\mathrm{Cz}-\mathrm{Si}$ no AR \#1 & -0.98 & 0.532 \\
\hline $\mathrm{Cz}-\mathrm{Si}$ no AR \#2 & -1.38 & 0.605 \\
\hline
\end{tabular}

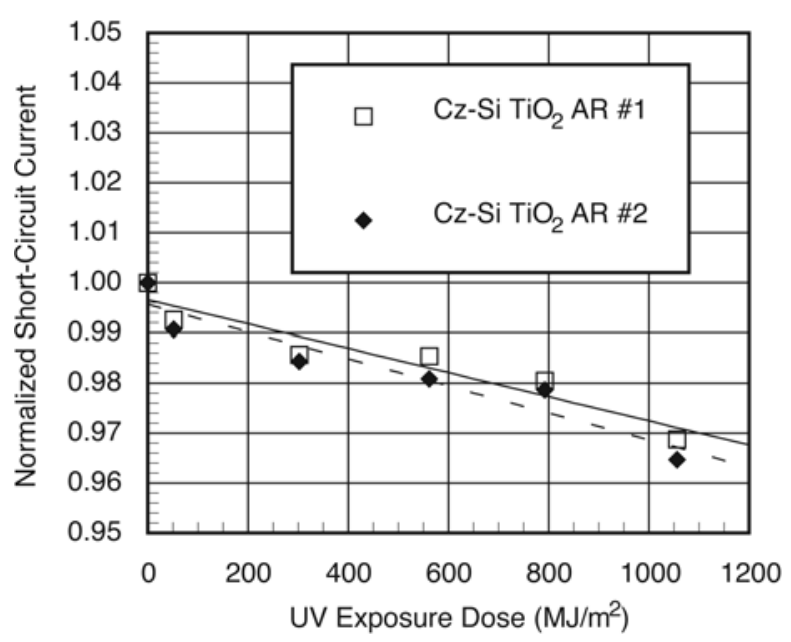

Fig. 3. Normalized $I_{s c}$ versus total UV exposure dose for the $\mathrm{Cz}-\mathrm{Si}$ samples with $\mathrm{TiO}_{2}$ AR coating and encapsulated with EVA in module-style packages under Solatex superstrates. 


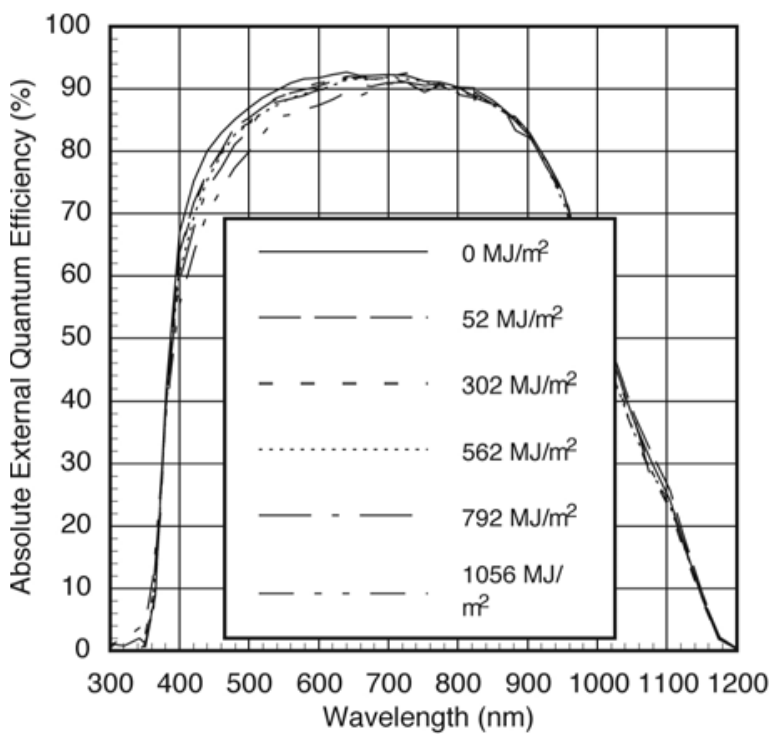

Fig. 4. Absolute external $\mathrm{QE}$ versus wavelength and total UV exposure dose for $\mathrm{Cz}-\mathrm{Si}$ sample \#2 with $\mathrm{TiO}_{2} \mathrm{AR}$ coating and encapsulated with EVA under Solatex superstrates.

\section{Unencapsulated samples}

Table 2 lists the $\mathrm{I}_{\mathrm{sc}}$ linear degradation rates with corresponding correlation coefficients for the unencapsulated samples. The linear fits are illustrated in Fig. 5 for the cast-Si $\mathrm{TiO}_{2}$ samples. Although the degradation in Fig. 5 is not large, it appears to be greater than the $\pm 1 \% I_{\text {sc }}$ measurement repeatability, as seen in Figs. 1 and 2 . The medium values of the correlation coefficients could indicate that UV dose is not the only cause of the degradation. It is interesting to note that there does not appear to be any differentiation between the cell types, unlike the EVAencapsulated samples. There are no clear trends in the QE data that might indicate specific wavelength regions in which the losses are occurring.

\begin{tabular}{|c|c|c|}
\hline Sample & $\begin{array}{c}\text { Rate } \\
\left(\% / \mathrm{GJ} / \mathrm{m}^{2}\right)\end{array}$ & $r^{2}$ \\
\hline Cast-Si TiO 2 AR \#1 & -1.16 & 0.428 \\
\hline Cast-Si TiO 2 AR \#2 & -1.39 & 0.558 \\
\hline $\mathrm{Cz}-\mathrm{Si} \mathrm{TiO}_{2} \mathrm{AR} \# 1$ & -1.11 & 0.672 \\
\hline $\mathrm{Cz}-\mathrm{Si} \mathrm{TiO} 2$ AR \#2 & -1.36 & 0.505 \\
\hline Cz-Si no AR \#1 & -1.93 & 0.849 \\
\hline Cz-Si no AR \#2 & -0.72 & 0.276 \\
\hline
\end{tabular}

Table 2. $I_{\mathrm{sc}}$ degradation rates and linear-fit correlation coefficients for the unencapsulated samples.

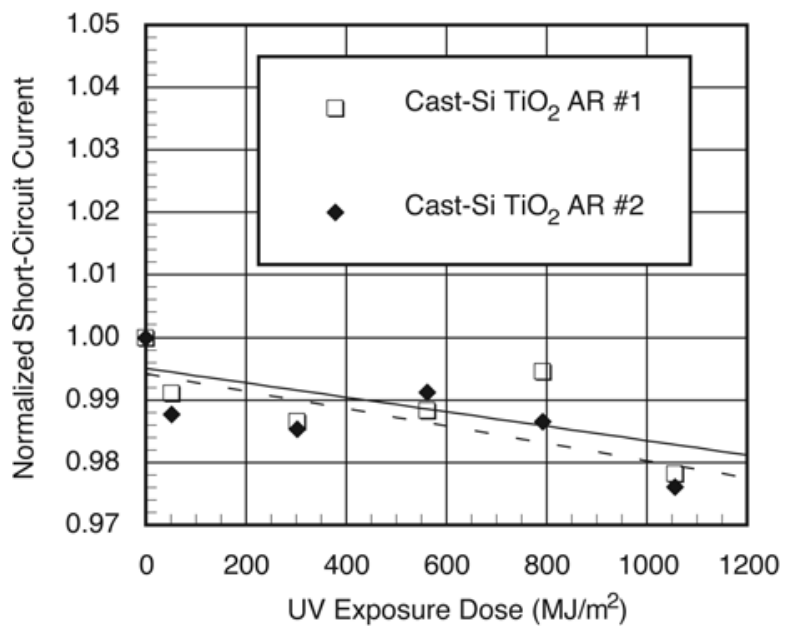

Fig.5. Normalized $\mathrm{I}_{\mathrm{sc}}$ versus total UV exposure dose for the unencapsulated cast-Si samples.

\section{UV-blocking superstrate samples}

At this point in the test program, it is apparent that the Schott GG495 UV-blocking superstrates are not stable enough for studying $I_{s c}$ degradation. The instability is evident in the large swings in Fig. 6, which plots the normalized $\mathrm{I}_{\mathrm{sc}}$ results for the cast-Si with $\mathrm{TiO}_{2} \mathrm{AR}$ coating samples. Including the results for the $\mathrm{Cz}-\mathrm{Si}$ samples (Fig. 7), the plate-to-plate instabilities differ and are large enough to mask any changes in cell performance. It would be informative to study transmittance changes on a sample of GG495 glass as a function of UV exposure.

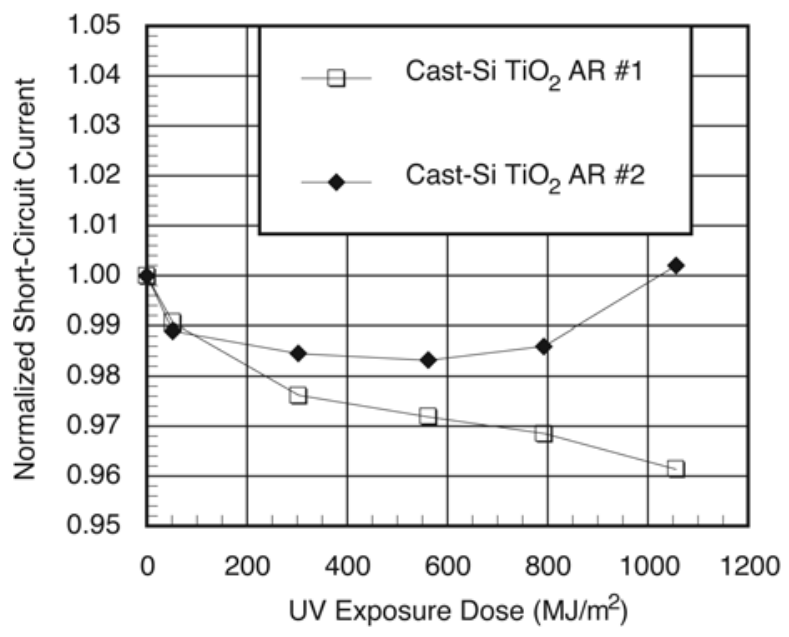

Fig. 6. Normalized $\mathrm{I}_{\mathrm{sc}}$ versus total UV exposure dose for the cast-Si samples encapsulated under UV-blocking GG495 superstrates with EVA. 


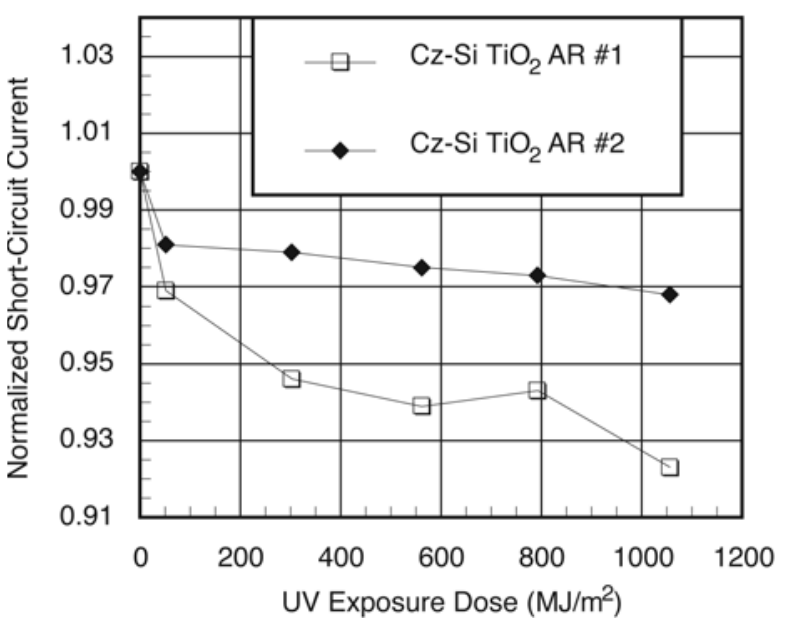

Fig. 7. Normalized $\mathrm{I}_{\mathrm{sc}}$ versus total UV exposure dose for the $\mathrm{Cz}-\mathrm{Si}$ samples encapsulated under UV-blocking GG495 superstrates with EVA.

\section{DISCUSSION AND CONCLUSIONS}

Undoubtedly the most disappointing results have to be with the UV-blocking superstrates. A way was needed to expose cells to light and at the same time prevent any UV radiation; colored-glass filters seemed to be the only solution. In hindsight, however, the transmittance instabilities of colored-glass filters are well known. It was hoped that the filters would stabilize after an initial exposure period of some length, but this has not yet occurred. Even if they do eventually stabilize, it would likely be impossible to draw any conclusions about changes in the cells.

The results from the unencapsulated and the Solatex/EVA encapsulated samples, on the other hand, are interesting and trends are becoming evident. First, the unencapsulated samples exposed only in the oven are unchanged, which would indicate that a solely thermal process is not responsible for losses of $I_{\text {sc }}$. This result is contrasted with the cells encapsulated under Solatex/EVA, which seem to be degrading linearly with respect to total UV dose in at least one case (Table 1 and Fig. 3). These $\mathrm{I}_{\mathrm{sc}}$ losses are occurring at wavelengths shorter than $700 \mathrm{~nm}$ (Fig. 4), which is consistent with EVA browning [4]. The interesting point so far is that the degradation rates vary with the cell type (Table 1), which is consistent with the previous results on modules [1]. If EVA browning is the only process occurring, one would expect the rates to be independent of cell type.
Lastly, $\mathrm{I}_{\mathrm{sc}}$ losses are beginning to be detectable in the unencapsulated cells (Table 2). These losses differ from those of the Solatex/EVA samples because so far they are all of similar magnitude, plus they do not appear to be wavelength-dependent. Soiling could explain these losses, but the appearance of these samples is still similar to those of the control and oven samples. Also, a simple cleaning step at the end of the long-term testing should indicate if soiling is responsible.

\section{ACKNOWLEDGEMENTS}

The authors thank Spire Corp. and Steve Hogan for performing all the laminations on the cell samples. This work is supported by the U.S. Department of Energy under Contract No. DE-AC36-99G010337.

\section{REFERENCES}

[1] C.R. Osterwald, J.P. Benner, J. Pruett, A. Anderberg, S. Rummel, and L. Ottoson, "Degradation in Weathered Crystalline-Silicon PV Modules Apparently Caused by UV Radiation," Proc. 3rd World Conf. on PV Energy Conversion, Osaka, Japan, 2003, ISBN 4-9901819-3-8.

[2] C.R. Osterwald, A. Anderberg, S. Rummel, and L. Ottoson, "Degradation Analysis of Weathered CrystallineSilicon PV Modules," Proc. 29th IEEE PV Spec. Conf., Piscataway, NJ, 2002, pp. 1392-1395.

[3] C.R. Osterwald, J. Pruett, D.R. Myers, S. Rummel, A. Anderberg, L. Ottoson, and T. Basso, "Real-Time and Acclerated Solar Weathering of Commercial PV Modules," Proc. 2001 NCPV Prog. Rev. Meeting, NREL, Golden, CO, 2001, p. 309.

[4] F.J. Pern and S.H. Glick, "Photothermal Stability of Encapsulated Si Solar Cells and Encapsulation Materials Upon Accelerated Exposures," Solar Energy Materials \& Solar Cells, 61 (2000), pp. 153-188.

[5] ASTM International Standard E 948, "Standard Test Method for Electrical Performance of Photovoltaic Cells Using Reference Cells Under Simulated Sunlight," Annual Book of ASTM Standards, Vol. 12.02, 2004.

[6] T. Saitoh, H. Hasigami, S. Rein, and S. Glunz, "Overview of Light Degradation Research on Crystalline Silicon Solar Cells," Prog. in PV: Research and Applications, 8, 537 (2000) 


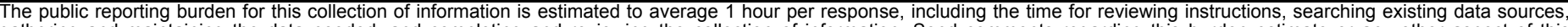

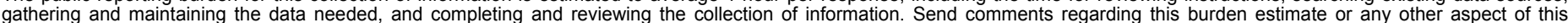

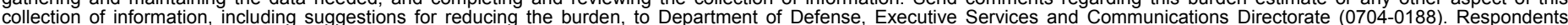

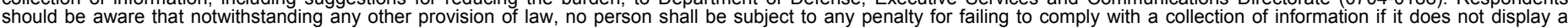

should be aware that notwithstand

PLEASE DO NOT RETURN YOUR FORM TO THE ABOVE ORGANIZATION.

\section{REPORT DATE (DD-MM-YYYY) \\ February 2005 \\ 2. REPORT TYPE \\ Conference Paper}

4. TITLE AND SUBTITLE

Crystalline Silicon Short-Circuit Current Degradation Study: Initial

Results
3. DATES COVERED (From - To)

3-7 January 2005

5a. CONTRACT NUMBER

DE-AC36-99-G010337

5b. GRANT NUMBER

5c. PROGRAM ELEMENT NUMBER

5d. PROJECT NUMBER

NREL/CP-520-37357

5e. TASK NUMBER

PVB57101

5f. WORK UNIT NUMBER
7. PERFORMING ORGANIZATION NAME(S) AND ADDRESS(ES)

National Renewable Energy Laboratory

1617 Cole Blvd.

Golden, CO 80401-3393
8. PERFORMING ORGANIZATION REPORT NUMBER

NREL/CP-520-37357

9. SPONSORING/MONITORING AGENCY NAME(S) AND ADDRESS(ES)

10. SPONSOR/MONITOR'S ACRONYM(S) NREL

11. SPONSORING/MONITORING AGENCY REPORT NUMBER

12. DISTRIBUTION AVAILABILITY STATEMENT

National Technical Information Service

U.S. Department of Commerce

5285 Port Royal Road

Springfield, VA 22161

\section{SUPPLEMENTARY NOTES}

\section{ABSTRACT (Maximum 200 Words)}

Following our observation of slow degradation of short-circuit current $\left(I_{s c}\right)$ in crystalline silicon ( $x$-Si) modules that was correlated with ultraviolet (UV) exposure dose, we initiated a new study of individual $x$-Si cells designed to determine the degradation cause. In this paper, we report the initial results of this study, which has accumulated $1056 \mathrm{MJ} / \mathrm{m}^{2}$ of $\mathrm{UV}$ dose from 1-sun metal-halide irradiance, equivalent to 3.8 years at our test site. At this time, the control samples are unchanged, the unencapsulated samples have lost about $2 \%$ of $\mathrm{I}_{\mathrm{sc}}$, and the samples encapsulated in module-style packages have declined from $1 \%$ to $3 \%$, depending on the cell technology.

\section{SUBJECT TERMS}

PV; crystalline silicon (x-Si); short-circuit current $\left(\mathrm{I}_{\mathrm{sc}}\right)$; module; ultraviolet (UV); metal-halide irradiance;

\begin{tabular}{|c|c|c|}
\hline $\begin{array}{l}\text { a. REPORT } \\
\text { Unclassified }\end{array}$ & $\begin{array}{l}\text { b. ABSTRACT } \\
\text { Unclassified }\end{array}$ & $\begin{array}{l}\text { c. THIS PAGE } \\
\text { Unclassified }\end{array}$ \\
\hline
\end{tabular}

\begin{tabular}{l|l} 
17. LIMITATION & 18. \\
OF ABSTRACT & OF PAGES \\
UL & \\
& \\
\hline
\end{tabular}

19a. NAME OF RESPONSIBLE PERSON

19b. TELEPHONE NUMBER (Include area code) 